\title{
Effect of intramammary infection in Bergamasca meat sheep on milk parameters and lamb growth
}

\author{
Paolo Moroni ${ }^{1}$, Giuliano Pisoni ${ }^{1}$, Giorgio Varisco ${ }^{2}$ and Paul Boettcher ${ }^{3}$ \\ ${ }^{1}$ Department of Veterinary Pathology, Hygiene and Public Health, University of Milan, via Celoria 10, Milan, Italy \\ ${ }^{2}$ Department of Food Safety, Istituto Zooprofilattico of Lombardia and Emilia Romagna Brescia 25124, Italy \\ ${ }^{3}$ Institute of Agricultural Biology and Biotechnology, National Research Council, Milan Palazzo LITA, Milan, Italy
}

Received 26 October 2006 and accepted for publication 20 February 2007

\begin{abstract}
Pooled milk samples from 115 Bergamasca meat sheep were collected aseptically five times from lambing to weaning to determine the prevalence of intramammary infection, somatic cell counts and milk quality parameters (protein, fat and lactose), and effects of infection on lamb weight gain. The global prevalence of subclinical intramammary infection was $51 \cdot 2 \%$. The Staphylococcus genus was responsible for the greatest prevalence $(53.3 \%$ among infected udders). Staphylococcus aureus was isolated in $8.4 \%$ of infected milk samples. Infection status had significant effects on fat and protein percentage and on somatic cell count. Lamb growth was greatest for lambs of ewes with no infection and decreased as the number of infected samples increased. No significant differences were detected in the growth of lambs with dams infected by different bacterial species.
\end{abstract}

Keywords: Intramammary infection, meat sheep, lamb growth, milk parameters, somatic cell.

The sheep population in Italy is estimated at approximately 8200000 head (FAO, 2005) of which $15 \%$ are meatproducing sheep. Bergamasca sheep number about 95000 head and are concentrated mostly in Lombardy, where the animals typically graze under a nomadic system. Elsewhere they are housed for part or all of the year. Sheep have traditionally been marketed as wethers at 16-18 months of age, but the present trend is moving towards the production of lambs to be sold at 3-4 months. The average lactational milk yield is $160-180 \mathrm{~kg}$ per ewe and milk production is the main factor influencing lamb growth during the preweaning stage (Susmel \& Piasentier, 1989).

Perhaps logically, most studies conducted on mastitis in sheep have been focused on dairy animals. Intramammary infections (IMI) and subclinical mastitis in dairy sheep may adversely affect milk production, increase the somatic cell count (SCC) and decrease milk quality (Bergonier et al. 2003). In dairy sheep flocks, IMI prevalences of 22-48\% (Fthenakis, 1994) and up to $40 \%$ (Leitner et al. 2001) has been reported.

The objectives of this study were to determine (1) the relationship of IMI in ewes raised for meat production with growth of suckling lambs, including the effect of the pathogen responsible and (2) the relationships between

\footnotetext{
*For correspondence; e-mail: paolo.moroni@unimi.it
}

infection and concentrations of fat, protein, lactose and somatic cells in the milk.

\section{Materials and Methods}

The sheep flock, free from brucellosis and mycoplasmosis after serological analysis, used for this investigation was in northern Italy, and consisted of 300 winter-lambing Bergamasca ewes grazing upland pasture (intermediate altitude, often improved pasture grazed with a medium stocking density).

For two consecutive lambing seasons (OctoberFebruary of 2002-2003 and 2003-2004) 20\% of the flock's ewes were randomly selected to be included in the study and no ewe was sampled for two consecutive seasons. Based on simple preliminary estimates, this proportion was expected to provide sufficient power to detect a difference of at least $1.0 \mathrm{~kg}$ in the growth of offspring from healthy and infected ewes. Data were recorded for 61 and 54 ewes in the 2002-2003 and 2003-2004 seasons, respectively. At parturition, each ewe and her lambs were placed in a small pen $(1.5 \times 1 \cdot 2 \mathrm{~m})$ for $1-2 \mathrm{~d}$. Then ewes and lambs were moved to a mixing pen with 10-15 other ewes and their lambs, for about 1 week. Finally, ewes and lambs were moved to a larger rearing pen, with 15-70 other ewes and their lambs. Lambs were 
routinely reared by their birth-dam until weaning at approximately 55-60 d of age. All lambs were identified with their dam and ear-tagged within $12 \mathrm{~h}$ of birth. Numbered collars were used to identify the ewes and their respective lambs. Lambs were weighed at birth and 3, 8, 13, 18 and $50 \mathrm{~d}$ of age and were not supplemented with any solid feed until weaning. Milk samples were also collected at the same time, starting from day 3. For milk collection, lambs were removed and isolated from ewes for the $8 \mathrm{~h}$ prior to sampling. The teats of the ewes were carefully cleaned using cotton swabs and chlorhexidine. The first streams of foremilk were discharged, and then $50 \mathrm{ml}$ of milk was collected aseptically by hand milking from both sides of the udder and pooling the two samples together. Samples were kept at $4{ }^{\circ} \mathrm{C}$ until bacteriological assay, SCC test, fat, protein and lactose concentrations determinations were performed. None of the ewes studied showed evidence of clinical (chronic or acute) mastitis at the time of sampling.

\section{Microbiological analysis}

Bacteriological culturing of pooled milk samples was performed according to Clements et al. (2003) and to the International Dairy Federation (FIL-IDF, 1981). Bacteriological interpretation was based on the National Mastitis Council recommendations (NMC, 1999).

\section{Determination of SCC and concentrations of protein, fat and lactose}

For each milk sample, SCC was determined by an automated fluorescent microscopic somatic cell counter (Bentley Somacount 150, Bentley Instruments, USA). Ethidium bromide dye was used for specific binding to the DNA in the cell nuclei. Percentages of milk fat, protein and lactose were determined on composite milk samples and assayed by an automated FT (Fourier Transformed) infrared absorption spectrophotometric analyser (Milkoscan, Foss, Denmark). For analytical and statistical evaluation, SCC were logarithmically transformed to somatic cell scores (SCS) on the base 2 (SCS $=\log _{2}(\mathrm{SCC})$ $100000)+3)$, according to Ali \& Shook (1980).

\section{Statistical Analysis}

Relationship between mammary infection and growth: The relationship between growth and mammary infection was examined in two ways. First, the total increase in weight from birth to $50 \mathrm{~d}$ was used as the dependent variable and analysed with a model that included number of sample days with infection as an independent variable. For this analysis, the number of sampling occasions on which a sample yielded bacteria (out of five sampling occasions) was classified into four different categories according to bacteriological results: $1=$ no infected samples (out of 5); $2=$ one infected sample; $3=$ two infected samples; $4=$ three to five infected samples. Preliminary analyses had revealed no difference in growth for the lambs of ewes with between three and five infected samples. The other factors in this model were fixed effects of season of lambing; litter size (single or twin); parity of the ewe (from first to fourth); and linear regressions on concentrations of fat, protein and lactose. Preliminary analyses had demonstrated that interactions among fixed effects were non-significant. Ewe was included as a random effect to account for repeated records. Concentrations of the milk components were averages across the five sample dates and weighted according to the number of days between samples. The MIXED procedure of SAS (SAS, 2000) was used for this and all other statistical analyses.

In the second set of analyses, the relationship between various measures of growth and infection was examined separately for each of the five sampling periods (in days $0-3$, days $3-8$, etc.). For this analysis, T2 models were evaluated. For the first, infection status was simply recorded as either infected or healthy. For the second model, the species of the pathogen was considered. The infection status was assigned to six classes: (1) negative (no infection), (2) CNS (coagulase negative staphylococci), (3) Staphylococcus aureus, (4) Bacillus spp., (5) Gramnegative bacteria and (6) other Gram-positive bacteria. The model included the infection type at both the start and the end of the period evaluated as separate factors in the model. For example, the model evaluating the effect of infection on growth between days 18 and 50 had one effect for infection type at day 18 and another for status at day 50 . This approach was taken because the type species of bacteria detected was occasionally different at the start and the end of the periods. The other factors in the model were the same as for the analysis of total weight gain during the entire 50-d period.

Factors affecting milk components: Two models were also applied for the relationships between various factors and concentrations of fat, protein, lactose and somatic cells. Of particular interest was the effect of IMI. The first considered infection as a general dichotomous (healthy/ infected) variable; the second considered the same grouping of bacteria as was used for growth. Other fixed effects in the model were season, parity, litter size, and sample number, and ewe was as a random effect. These analyses considered 560 records.

\section{Results}

A total of 169 lambs were included in the study, 61 raised as single lambs and 108 raised as twins. Eight lambs died during the study period from respiratory problems. Mean lamb weight at birth was $5.56 \mathrm{~kg}$ (SD 0.68), with a range of $3.45-7 \cdot 10 \mathrm{~kg}$. At birth, twins had a mean weight of $5.36 \mathrm{~kg}$ (SD 0.53), which was less than the average weight 
Table 1. Proportion of samples from Bergamasca sheep infected by various mammary pathogens

Frequency overall proportion proportion of infected

Pathogen

Negative

Staphylococcus aureus

Staphylococcus xylosus

Staphylococcus simulans

Streptococcus spp.

Bacillus spp.

Pseudomonas aeruginosa

Proteus vulgaris

Corynebacterium spp.

Aeromonas hydrophila

Hafnia alvei

Acinetobacter spp.

Aerococcus viridans

Klebsiella spp.
$\%$

$$
48 \cdot 75
$$

$4 \cdot 28$

$16 \cdot 96$

$3 \cdot 58$

$2 \cdot 5$

$5 \cdot 36$

$7 \cdot 31$

$7 \cdot 31$

$1 \cdot 25$

$0 \cdot 54$

$0 \cdot 54$

$0 \cdot 54$

$0 \cdot 54$

$0 \cdot 18$

$0 \cdot 18$

$0 \cdot 18$

\begin{tabular}{r}
- \\
\hline $8 \cdot 36$ \\
$33 \cdot 10$ \\
$6 \cdot 97$ \\
$4 \cdot 87$ \\
$10 \cdot 45$ \\
$14 \cdot 28$ \\
$14 \cdot 28$ \\
$2 \cdot 44$ \\
$1 \cdot 05$ \\
$1 \cdot 05$ \\
$1 \cdot 05$ \\
$1 \cdot 05$ \\
$0 \cdot 35$ \\
$0 \cdot 35$ \\
$0 \cdot 35$
\end{tabular}

Staphylococcus epidermidis

Pantoea spp.

of single lambs of $5.78 \mathrm{~kg}$ (SD 0.76). At the end of the study (50 d) lambs reached a mean weight of $18 \cdot 1 \mathrm{~kg}$ (SD 4.1), with a range of $8 \cdot 8-25 \cdot 0 \mathrm{~kg}$. At the end of the study $(50 \mathrm{~d})$, twins reached a mean weight of $16.4 \mathrm{~kg}$ (SD 3.54), which was less than the single lamb average weight of $19.9 \mathrm{~kg}$ (SD 3·60).

\section{Prevalence of intramammary infection}

A total of 562 milk samples were collected from 115 lactating ewes. Of the total samples obtained, none corresponded to cases of clinical (chronic or acute) mastitis, 273 to negative cultures, 287 to positive cultures and 2 to contaminated cultures. The contaminated cultures represented $<1 \%$ of samples from asymptomatic glands, a value very similar to that obtained in other studies of dairy ewes (Ariznabarreta et al. 2002; Marco, 1994), and were excluded from the study. The global prevalence of subclinical IMI was $51 \cdot 2 \%$. Table 1 shows the relative prevalence of each genus, group and bacterial species for total isolates. Thus, the Staphylococcus genus was most commonly responsible for subclinical infections, with a global prevalence of $53.3 \%$ among infected udder halves. Coagulase-negative staphylococci represented $44.9 \%$ of infected samples: the most frequently isolated species was Staph. epidermidis $(73.6 \%)$, followed by Staph. xylosus $(15.5 \%)$ and Staph. simulans $(10.9 \%)$. The main contagious pathogen, Staph. aureus, was isolated in $8.36 \%$ of infected milk samples. Pseudomonas aeruginosa and Bacillus spp., isolated in the same percentage (14.3\%) of infected udders, were the second most prevalent pathogens. Streptococcus spp. was isolated in $10.4 \%$ of infected samples while other genera (Gram-negative and Grampositive microrganisms) had a prevalence of $<3 \%$.
Table 2. Least square means and their standard errors(SE) of weight gain from birth to $50 \mathrm{~d}$ as a function of the number of sample days (out of five) at which intramammary infection was recorded

\begin{tabular}{llll}
$\begin{array}{l}\text { Number of } \\
\text { infections }\end{array}$ & $\begin{array}{l}\text { Lambs } \\
\text { number }\end{array}$ & Gain $(\mathrm{kg})$ & \multicolumn{1}{l}{ SE } \\
0 & 33 & $14 \cdot 75^{\mathrm{a}}$ & $0 \cdot 70$ \\
1 & 17 & $14 \cdot 17^{\mathrm{ab}}$ & $0 \cdot 74$ \\
2 & 27 & $12 \cdot 42^{\mathrm{bc}}$ & $0 \cdot 68$ \\
3 to 5 & 84 & $11 \cdot 25^{\mathrm{c}}$ & $0 \cdot 40$ \\
a,b,c Least square means sharing a superscript letter were not significantly \\
different $(P>0 \cdot 05)$
\end{tabular}

Table 3. Least square means of body weight gain $(\mathrm{kg})$ during five periods in the early lives of lambs from ewes with healthy or infected mammary glands

\begin{tabular}{|c|c|c|c|c|}
\hline Period & $n$ & Healthy & Infected & $P$-value \\
\hline Days 0-3 & 169 & 0.66 & $0 \cdot 71$ & $0 \cdot 38$ \\
\hline Days 4-8 & 167 & $1 \cdot 33$ & $1 \cdot 12$ & $0 \cdot 02$ \\
\hline Days 9-13 & 164 & $1 \cdot 22$ & 1.09 & $0 \cdot 14$ \\
\hline Days $14-18$ & 161 & $2 \cdot 18$ & $1 \cdot 14$ & $<0.000$ \\
\hline Days $19-50$ & 161 & $8 \cdot 05$ & $7 \cdot 26$ & 0.06 \\
\hline
\end{tabular}

\section{Relationships between mammary infection and lamb growth}

Table 2 shows the least square means in growth as a function of number of infections. Growth was greatest for the lambs of ewes with no infections and decreased as the number of infected samples increased. The greatest difference corresponding to a marginal increase of one infection was between 1 and 2 infections $(1.75 \mathrm{~kg})$. The $P$-value for this difference was 0.06.

Among the other factors included in this model, effects of litter size and fat concentration were significant $(P \leqslant 0.001$ for both). The least square means for growth were $14 \cdot 2 \mathrm{~kg}$ for single lambs $v \cdot 12 \cdot 1 \mathrm{~kg}$ for twins. Weight gain increased by $0.84 \mathrm{~kg}$ for each percent increase in fat content. Effects of lambing season, ewe parity and percentages of protein and lactose were not significant.

Table 3 shows the comparison of growth for offspring of healthy and infected ewes, broken down by separate periods. In all periods except the first, the weight gain was greater for lambs with uninfected dams. The difference was significant $(P<0 \cdot 05)$ for days $4-8$ and $14-18$ and approached significance for the period between days 19 and 50. The greatest difference between healthy and infected classes was for the period from days 14 to 18 , which was somewhat surprising, considering that this period was shorter than the final period. With regard to other factors in the model, litter size had a significant effect in all periods except the first. Other factors were significant in some periods, but with no strong and 
Table 4. Least square means of concentrations of fat, protein, lactose and somatic cells ( $\mathrm{SCS}=\log _{2}$ transformed) for lambing season, parity, sampling date, litter size, infection status expressed either as healthy and infected or by pathogen

\begin{tabular}{|c|c|c|c|c|c|}
\hline \multirow[b]{3}{*}{ Factor } & \multirow[b]{3}{*}{$n+$} & \multicolumn{3}{|c|}{ Milk component } & \multirow[b]{3}{*}{ SCS } \\
\hline & & Fat & Protein & Lactose & \\
\hline & & \multicolumn{3}{|c|}{ - } & \\
\hline \multicolumn{6}{|l|}{ Lambing season } \\
\hline 2002-2003 & 298 & $7 \cdot 51^{\mathrm{a}}$ & $5 \cdot 34^{\mathrm{a}}$ & $5 \cdot 15^{\mathrm{a}}$ & $3 \cdot 91^{\mathrm{a}}$ \\
\hline 2003-2004 & 262 & $7 \cdot 47^{\mathrm{a}}$ & $5 \cdot 41^{\mathrm{a}}$ & $5 \cdot 16^{\mathrm{a}}$ & $4 \cdot 88^{b}$ \\
\hline \multicolumn{6}{|l|}{ Parity } \\
\hline 1 & 117 & $7 \cdot 02^{\mathrm{a}}$ & $5 \cdot 15^{\mathrm{a}}$ & $5 \cdot 21^{a}$ & $4 \cdot 65^{\mathrm{a}}$ \\
\hline 2 & 120 & $7 \cdot 07^{\mathrm{a}}$ & $5 \cdot 27^{\mathrm{a}}$ & $5 \cdot 16^{\mathrm{a}}$ & $4 \cdot 61^{\mathrm{a}}$ \\
\hline 3 & 150 & $8 \cdot 10^{\mathrm{b}}$ & $5 \cdot 54^{\mathrm{b}}$ & $5 \cdot 18^{\mathrm{a}}$ & $3 \cdot 60^{\mathrm{b}}$ \\
\hline 4 & 173 & $7 \cdot 79^{\mathrm{b}}$ & $5 \cdot 56^{\mathrm{b}}$ & $5 \cdot 05^{b}$ & $4 \cdot 71^{\mathrm{a}}$ \\
\hline \multicolumn{6}{|l|}{ Day of sampling } \\
\hline 3 & 114 & $8 \cdot 20^{\mathrm{a}}$ & $5 \cdot 79^{\mathrm{a}}$ & $4 \cdot 98^{\mathrm{a}}$ & $4 \cdot 69^{\mathrm{a}}$ \\
\hline 8 & 113 & $7 \cdot 34^{\mathrm{bc}}$ & $5 \cdot 36^{b}$ & $5 \cdot 15^{b}$ & $4 \cdot 46^{\mathrm{a}}$ \\
\hline 13 & 112 & $6 \cdot 98^{\mathrm{b}}$ & $5 \cdot 07^{\mathrm{C}}$ & $5 \cdot 24^{\mathrm{c}}$ & $4 \cdot 10^{\mathrm{b}}$ \\
\hline 18 & 111 & $7 \cdot 32^{\mathrm{bc}}$ & $5 \cdot 00^{\mathrm{C}}$ & $5 \cdot 22^{\mathrm{bc}}$ & $4 \cdot 07^{b}$ \\
\hline 50 & 110 & $7 \cdot 63^{c}$ & $5 \cdot 67^{\mathrm{a}}$ & $5 \cdot 16^{\mathrm{bc}}$ & $4 \cdot 64^{\mathrm{a}}$ \\
\hline \multicolumn{6}{|l|}{ Litter size } \\
\hline Single & 357 & $7 \cdot 89^{\mathrm{a}}$ & $5 \cdot 43^{\mathrm{a}}$ & $5 \cdot 13^{a}$ & $4 \cdot 39^{a}$ \\
\hline Twin & 203 & $7 \cdot 10^{\mathrm{b}}$ & $5 \cdot 33^{a}$ & $5 \cdot 17^{\mathrm{a}}$ & $4 \cdot 39^{a}$ \\
\hline \multicolumn{6}{|l|}{ Pathogen $\neq$} \\
\hline None & 273 & $8 \cdot 02^{\mathrm{a}}$ & $5 \cdot 58^{\mathrm{a}}$ & $5 \cdot 10^{\mathrm{bc}}$ & $3 \cdot 01^{\mathrm{a}}$ \\
\hline CNS & 127 & $7 \cdot 40^{\mathrm{b}}$ & $5 \cdot 25^{b}$ & $5 \cdot 17^{\mathrm{b}}$ & $4 \cdot 36^{\mathrm{C}}$ \\
\hline$A \cup R$ & 24 & $6 \cdot 69^{b}$ & $5 \cdot 54^{\mathrm{abc}}$ & $5 \cdot 37^{\mathrm{a}}$ & $6 \cdot 38^{\mathrm{d}}$ \\
\hline $\mathrm{BAC}$ & 41 & $7 \cdot 51^{\mathrm{ab}}$ & $5 \cdot 20^{\mathrm{b}}$ & $5 \cdot 19^{a b}$ & $3.95^{\mathrm{C}}$ \\
\hline GRAM-ve & 68 & $7 \cdot 50^{\mathrm{b}}$ & $5 \cdot 47^{\mathrm{ad}}$ & $5 \cdot 15^{b}$ & $3 \cdot 80^{b}$ \\
\hline Other GRAM+ve & 27 & $7 \cdot 84^{\mathrm{ab}}$ & $5 \cdot 22^{\text {bd }}$ & $4 \cdot 96^{\mathrm{c}}$ & $4 \cdot 88^{\mathrm{C}}$ \\
\hline
\end{tabular}

$+n=$ number of observations from each subclass

$\neq \mathrm{CNS}=$ coagulase negative staphylococci, $\mathrm{A} \cup \mathrm{R}=$ Staphylococcus aureus, $\mathrm{BAC}=$ Bacillus

a,b,c,d Values in the same column and subsection of the table that share superscript letters were not significantly different $(P>0 \cdot 05)$

consistent general pattern except that increased fat percentage was consistently associated with increased weight gain.

When examining the effects of infections by different bacteria in different periods, the only significant effects observed were between healthy and infected animals (no table shown). No significant differences were detected in the growth of lambs with dams infected by different bacterial species. For the fourth period (days 14-18), the growth of lambs from healthy ewes was significantly greater than gain from lambs of infected ewes for all five bacterial groups. Among these groups, gain was lowest for offspring of ewes infected by Staph. aureus.

\section{Factors affecting milk components}

Table 4 presents least square means for different classes of effects included in the analyses of milk contents. Lambing season had little effect on most milk components, bar the
SCS, which were increased during the second lambing season (4.88 v. 3.91). Lactation number of ewe had significant relationships with all four component traits. An upward trend in concentrations of fat and protein was observed as parity increased. Stage of the lactation also had a significant effect on milk component concentrations (Table 4).

Number of lambs had a significant association only with fat percentage. Concentration of fat was much greater $(7 \cdot 89 v \cdot 7 \cdot 10)$ among ewes with single lambs than with twins. Infection status had significant detrimental effects on all concentrations, except lactose. SCS were strongly affected by infection status: infected ewes averaged $4 \cdot 34$ SCS $v$. only $3 \cdot 01$ for uninfected ones. The infective pathogen had significant effects on all measures of milk solids; Staph. aureus consistently had the most detrimental effects.

\section{Discussion}

The aim of this study was to establish whether the presence of IMI adversely affected milk parameters of meat breed ewes and growth of lambs. Lambs from uninfected dams gained $3.5 \mathrm{~kg}$ more $(P<0.05)$ than lambs from infected (any bacterial species of infection) dams during the age interval from 0 to $50 \mathrm{~d}$. Similarly, lambs from uninfected dams gained $3 \cdot 2 \mathrm{~kg}$ more than lambs from dams infected with Staph. aureus during the same time interval (data not shown). A number of plausible explanations can be presented for this decrease in growth. First, the ewes that were infected may have produced less milk as a result, decreasing the consumption by the young. Previous studies show a tendency for decreased milk yield of sheep both naturally (Gonzalo et al. 2002) and experimentally (Winter et al. 2003) infected with mammary pathogens. Demonstrating that the decreased growth was a result of decreased milk yield was not possible, however, with this study, as individual milk yield was not measured in the ewes. Decreased milk quality from infected ewes could also help explain the decreased growth. Such data were available from this study and concentrations of both fat and protein were lower in milk from infected ewes. Milk from infected ewes thus provided less energy and protein to support growth. Another possibility is that the bacteria in the milk from infected ewes may have directly decreased the health of the suckling lambs, by establishing new infections of other tissues in the lambs. However, no clinical evidence of sickness in the lambs fed infected milk was observed.

Decreased growth of suckling lambs was also observed in a study conducted on ewes experimentally infected with CNS (Fthenakis \& Jones, 1990b). Another study found that ewes receiving antibiotic treatment to prevent mastitis prior to parturition had heavier lambs at $50 \mathrm{~d}$ (Croft et al. 2000). The treated ewes had less subclinical mastitis, as indicated by palpable udder abnormalities, than did those 
receiving a placebo, but no difference in clinical mastitis was observed. A third study (Keisler et al. 1992) concluded that growth performance of lambs, in a management system where they had access to supplemental feed, was not influenced by the quality of milk produced by ewes, or by the degree of subclinical infection present when they suckled. The lambs in that study may have been able to consume solid feed to compensate for any deficit in milk production by their mothers, whereas lambs in our study were not supplemented with solid feed.

Comparison of growth for offspring of healthy and infected ewes, broken down by separate periods showed that, similarly to that found by Fthenakis \& Jones (1990a), most of the growth retardation occurred between days 14 and 18 after lambing, an age at which lambs are highly dependent on milk. The same period was also characterized by a significant decrease of milk quality parameters (fat and protein content). In addition to lamb growth, IMI had also a significant negative effect on fat and protein content and SCC.

\section{References}

Ali AKA \& Shook G 1980 An optimal transformation for somatic cell concentration in milk. Journal of Dairy Science 63 487-490

Ariznabarreta A, Gonzalo C \& San Primitivo F 2002 Microbiological quality and somatic cell count of ewe milk with special reference to Staphylococci. Journal of Dairy Science 85 1370-1375

Bergonier D, De Crémoux R, Rupp R, Lagriffoul G \& Berthelot X 2003 Mastitis of dairy small ruminants. Veterinary Research 34 689-716

Clements ACA, Taylor DJ \& Fitzpatrick JL 2003 Evaluation of diagnostic procedures for subclinical mastitis in meat-producing sheep. Journal of Dairy Research 70 139-148
Croft A, Duffield T, Menzies P, Leslie K, Bagg R \& Dick P 2000 The effect of tilmicosin administered to ewes prior to lambing on incidence of clinical mastitis and subsequent lamb performance. Canadian Veterinary Journal 41 306-311

FAOSTAT 2005 Agricultural Statistic (online: http://www.fao.org). Rome, Italy: FAO

FIL-IDF 1981 Laboratory Methods for Use in Mastitis Work. International Dairy Federation, IDF Bull. 132. Brussels, Belgium

Fthenakis GC \& Jones JET 1990a The effect of experimentally induced subclinical mastitis on milk yield of ewes and on the growth of lambs. British Veterinary Journal 146 43-49

Fthenakis GC \& Jones JET 1990b The effect of inoculation of coagulase negative staphylococci into the ovine mammary gland. Journal of Comparative Pathology 102 211-219

Fthenakis GC 1994 Prevalence and aetiology of subclinical mastitis in ewes of Southern Greece. Small Ruminant Research 13 293-300

Gonzalo C, Ariznabarreta A, Carriedo JA \& San Primitivo F 2002 Mammary pathogens and their relationship to somatic cell count and milk yield losses in dairy ewes. Journal of Dairy Science 85 14601467

Keisler DH, Andrews ML \& Moffat RJ 1992 Subclinical mastitis in ewes and its effect on lamb performance. Journal of Animal Science $\mathbf{7 0}$ 1677-1681

Leitner G, Chaffer M, Zamir S, Mor T, Glickman A, Winkler M, Weisblit L \& Saran A 2001 Udder disease aetiology, milk somatic cell count and NAGase activity in Israeli Assaf sheep throughout lactation. Small Ruminant Research 39 107-112

Marco JC 1994 [Mastitis in Laxta sheep: epidemiology, diagnosis and control]. Ph.D. Thesis, University of Saragoza, Spain

National Mastitis Council 1999 Laboratory Handbook on Bovine Mastitis, Revised Edition. Madison WI, USA: National Mastitis Council, Inc.

SAS Institute 2000 SAS/STAT User's Guide, Version 8. SAS Institute, Cary, USA

Susmel P \& Piasentier E 1989 Note on the Bergamasca breed of sheep. Symposium "Philostios", Fonte-Boa, Portugal. EUR Publication (No. 11893): 552-560

Winter P, Schilcher F, Fuchs K \& Colditz IG 2003 Dynamics of experimentally induced Staphylococcus epidermidis mastitis in East Friesian milk ewes. Journal of Dairy Research 70 157-164 